\title{
TOTAL BAKTERI ASAM LAKTAT, NILAI pH, DAN ADHESIVENESS SUSU BIFIDUS BERBAHAN BAKU SUSU DARI PETERNAKAN YANG BERBEDA DENGAN PENAMBAHAN EKSTRAK BUAH-BUAHAN LOKAL
}

\author{
LACTIC ACID BACTERIA, PH VALUE, AND ADHESIVENESS OF BIFIDUS MILK \\ DERIVED FROM VARIOUS LOCAL FARMS WITH FRUIT FORTIFICATION
}

\author{
Faradilla Bunga Tiska $^{1)}$, Ani Sustiyah ${ }^{1)}$, Ahmad Ni'matulah Al-Baarri' ${ }^{2}$ \\ ${ }^{1}$ Program Studi Peternakan, Fakultas Peternakan dan Pertanian Universitas Diponegoro, Semarang \\ ${ }^{2}$ Program Studi Teknologi Pangan, Fakultas Peternakan dan Pertanian Universitas Diponegoro, \\ Semarang \\ Email: albari@undip.ac.id
}

\begin{abstract}
Variation of farm location may be affected to the fresh milk quality since the environment and physiological factor could be directly exposed to the dairy cattle. This variation on milk quality may provide the variation on milk products. This research was done to analyse the quality of bifidus milk derived from two kinds of fresh milk sources. Since it has been recognized that the quality was differed among fresh milk and for supporting the growth of Bifidobacterium in milk, the local fruits extract, i.e. avocado, salak, and longan were fortified to the fresh milk. Total lactic acid bacteria, pH, and adhesiveness was then analysed after 6 hour incubation. Data showed that there was a remarkable decrease in $\mathrm{pH}$ value on bifidus milk without fruit extract fortification derived from both sources of fresh milk. The fortification of fruits extract hindered the decrease resulting in the not significant decrease in $\mathrm{pH}$ value at $6 \mathrm{~h}$ incubation. There was no remarkable increase in total of lactic acid bacteria and adhesiveness during incubation for 6 hour in both of milk sources. The fortification of fruit extract increased the bacteria growth resulting in the benefit on utilization of fruit extract to enhance the quality of bifidus milk.
\end{abstract}

Keywords: fresh milk quality, bifidus milk, lactic acid bacteria, $p H$ value, adhesiveness

\begin{abstract}
ABSTRAK
Kualitas susu yang dihasilkan setiap ternak berbeda-beda tergantung faktor fisiologis dan lingkungan. Hal ini akan berpengaruh pada kandungan nutrisi dalam susu yang dapat menentukan kualitas produk olahan. Tujuan penelitian ini adalah mengetahui kualitas susu yang difermentasikan dengan Bifidobacterium longum dan ditambah ekstrak buah dilihat dari total bakteri asam laktat, nilai $\mathrm{pH}$, dan daya lekat (adhesiveness) yang berasal dari peternakan berbeda. Analisis yang digunakan yaitu Uji-T dengan sampel bebas. Terdapat dua peternakan yang akan dibandingkan untuk mengetahui kualitas susu. Hasil penelitian menunjukkan bahwa susu bifidus yang berasal dari peternakan yang berbeda tanpa penambahan ekstrak buah memberikan pengaruh nyata $(\mathrm{p}<0,05)$ terhadap penurunan nilai $\mathrm{pH}$ tetapi tidak pada pertumbuhan total Bakteri Asam Laktat (BAL) dan adhesivenes. Jumlah total BAL pada susu bifidus yang berbahan baku susu segar dari peternakan yang berbeda berada pada kisaran normal yaitu $10^{7} \log \mathrm{CFU} / \mathrm{ml}$. Nilai $\mathrm{pH}$ susu bifidus dari kedua peternakan masih diatas 5 dan adhesiveness masih rendah (belum menggumpal). Terjadi peningkatan pertumbuhan total $\mathrm{BAL}$, nilai $\mathrm{pH}$, dan adhesiveness setelah diberi ekstrak buah. Penambahan buah berguna untuk menyetarakan kualitas susu bifidus yang berbahan baku susu sedengan kualitas rendah sehingga menjadi lebih baik.
\end{abstract}

Kata kunci: kualitas susu segar, susu bifidus, total BAL, pH, adhesiveness

\section{PENDAHULUAN}

Peternakan sapi perah merupakan bidang usaha yang mempunyai peluang untuk dikembangkan. Peluang pengembangan peternakan sapi perah didorong dengan tingginya kebutuhan susu di kalangan masyarakat. Susu dapat diolah menjadi berbagai macam produk yang mengandung nutrisi berupa protein, lemak, karbohidrat (laktosa), mineral dan vitamin yang baik bagi kehidupan manusia (Sunarlim, 2009). Produk dengan mutu yang berkulitas baik diperlukan bahan baku susu segar dengan kualitas yang baik pula. Perkembangan ilmu didukung dengan kemajuan teknologi dalam pembuatan produk, mendorong para ahli untuk mencoba membuat suatu produk yang dapat meningkatkan nilai nutrisi dan manfaat susu tersebut dengan suatu pengolahan tertentu. 
Susu bifidus adalah susu fermentasi dengan menggunakan Bifidobacterium longum. Susu bifidus merupakan salah satu produk susu fermentasi yang dikenal memiliki peranan penting bagi kesehatan tubuh. Peran positif susu bifidus bagi kesehatan terutama didukung oleh adanya bakteri asam laktat berupa Bifidobacterium longum (Permadi, 2013). Natural aditif yang bersumber dari ekstrak buah merupakan salah satu suplai yang dapat membantu Bifidobacterium longum untuk beradaptasi karena mengandung monosakarida berupa glukosa dan fruktosa yang dapat membuat bakteri ini bertahan hidup lebih lama serta dapat juga digunakan untuk menambah cita rasa pada susu bifidus.

Manfaat dari penelitian ini adalah diharapkan dapat memberikan informasi tentang total BAL, nilai $\mathrm{pH}$, dan analisa tekstur dalam susu bifidus dengan penambahan ekstrak buah serta memberikan suatu alternatif dalam untuk meningkatkan diversifikasi pangan dengan memanfaatkan produksi susu di peternak untuk dijadikan susu fermentasi dan memanfaatkan sumber keberadaan buah lokal yang memiliki kandungan nutrien sehingga dapat meningkatkan citarasa bahkan meningkatkan manfaat susu bifidus bagi kesehatan.

\section{Bahan dan Alat}

Penelitian ini dilaksanakan pada bulan Desember 2013 sampai April 2014 di Sub Laboratorium Teknologi Pangan Laboratorium Terpadu Universitas Diponegoro dan Laboratorium Kimia dan Gizi Pangan, Fakultas Peternakan dan Pertanian, Universitas Diponegoro. Analisis data yang digunakan yaitu dengan menggunakan uji-T. Data yang diperoleh perlu dilakukan homogenitas data dengan menggunakan uji $\mathrm{F}$ terlebih dahulu.

\section{Bahan}

Bahan yang digunakan dalam penelitian ini antara lain susu segar yang diperoleh dari peternakan di daerah Gedawang (peternakan A) dan Salatiga (peternakan B), kultur starter (Bifidobacterium sp) yang diperoleh dari PAU Universitas Gadjah Mada, ekstrak buah (alpukat, kelengkeng dan salak), susu Ultra
High Temperature (UHT) alkohol, aquades, serta medium Man Ragosa and Sharp (MRS) Broth.

\section{Alat}

Alat yang digunakan adalah autoklaf, inkubator, sentrifuge, mortal, termometer, mikro pipet, micro tube, centrifuge tube 15 ml, timbangan elektrik, alumunium foil, kain penyaring, $\mathrm{pH}$ meter elektronik, erlenmeyer, petri film, gelas ukur, gelas beker, serta texture analyzer.

\section{METODE}

Susu yang telah diperoleh, kemudian langsung diuji kandungan protein, lemak, dan laktosa dengan menggunakan lactoscan dan pengujian ini dilakukan sebanyak tiga kali. Susu yang telah diuji kualitasnya ini, kemudian langsung digunakan sebagai bahan baku pembuatan susu bifidus. Proses sterilisasi yang dilakukan adalah dengan menggunakan prinsip non-thermal yaitu dengan menggunakan Lactoperoxidase system (Villa et al., 2014).

Proses pembuatan susu bifidus dimulai dengan mencampurkan susu segar dengan ekstrak buah $(3 \% \mathrm{v} / \mathrm{v})$ lalu ditambahkan komponen Lactoperoxidase System lalu dibiarkan selama 1 jam untuk membiarkan zat aktif dari produk Lactoperoxidase System, yaitu hypothiocyanite, bekerja dengan sempurna. Komponen untuk menghasilkan hypothiocyanite terdiri dari lactoperoxidase (LPO), kalium thiocyanate (KSCN) dan hydrogen peroxida (H2O2).

Komposisi Lactoperoxidase system terdiri dari 4,5 U/ml LPO, 0,3 $\mathrm{mM} \mathrm{KSCN}$ dan $0,3 \mathrm{mM} \mathrm{H}_{2} \mathrm{O}_{2}$. Ketiga komponen ini didiamkan selama 60 menit dan kemudian dicampurkan ke dalam susu yang tidak mengandung atau mengandung ekstrak buah dengan konsentrasi $20 \% \quad(\mathrm{v} / \mathrm{v})$. Setelah dimasukkan ke dalam susu, maka sampel dibiarkan selama 30 menit. Setelah itu susu diinokulasi dengan starter B. longum ATCC 15707 yang telah dipersiapkan sebelumnya sebanyak $10 \%$ v/v. Starter B. longum ATCC 15707 ini telah dihitung kepadatannya sebanyak $10^{6}-10^{7} \mathrm{CFU} / \mathrm{ml}$. Setelah proses inokulasi, dilakukan proses inkubasi pada suhu $37{ }^{\circ} \mathrm{C}$ selama 6 jam. Tiap jam, sampel dianalsis nilai $\mathrm{pH}$ (dengan menggunakan $\mathrm{pH}$ 
meter), total bakteri asam laktat (dengan menggunakan perhitungan dalam petrifilm 3M), dan adhesiveness (dengan menggunakan texture analyzer Brookfield CT-3).

Perlakuan yang dicobakan dalam penelitian ini adalah:

T0=Susu bifidus tanpa penambahan ekstrak buah

$\mathrm{T} 1=$ Susu bifidus dengan penambahan ekstrak buah alpukat

T2=Susu bifidus dengan penambahan ekstrak buah salak

T3=Susu bifidus dengan penambahan ekstrak buah kelengkeng

Data dianalisis menggunakan uji-t yang sebelumnya telah di homogenitaskan dengan uji $\mathrm{F}$ pada taraf signifikasi $5 \%$.

\section{HASIL DAN PEMBAHASAN}

\section{Kualitas Bahan Baku Pembuatan Susu Bifidus}

Hasil analisis komposisi susu segar di peternakan A dan peternakan B disajikan pada Tabel 1. Berdasarkan tabel tersebut, maka dapat dilihat bahwa komposisi susu segar mempunyai keragaman dalam hal kuantitas.

Tabel 1. Komposisi susu segar yang diambil dari peternakan di daerah Gedawang (Peternakan A) dan daerah Salatiga (Peternakan B)

\begin{tabular}{ccc}
\hline \multirow{2}{*}{ Komposisi } & Peternakan A & Peternakan B \\
\cline { 2 - 3 } & \multicolumn{2}{c}{--------- } \\
\hline Protein & 2,5 & 2,4 \\
Lemak & 2,8 & 3,7 \\
Laktosa & 2,9 & 3,0 \\
\hline
\end{tabular}

Keterangan: Hasil analisa merupakan rerata dari tiga kali ulangan

Berdasarkan data yang berada pada Tabel 1 kualitas susu segar yang terdapat pada peternakan A dan B masih berada dibawah kisaran normal sesuai dengan standar nasional kualitas susu segar di Indonesia (SNI, 2011). Berdasarkan hasil analisis laboratorium, kadar protein susu yang didapat dari peternakan A dan B didapat hasil masing-masing sebesar $2,5 \%$ dan $2,4 \%$. Kadar protein yang masih berada dibawah kualitas SNI ini dapat terjadi karena pengaruh faktor pakan dan genetik ternak.

Kadar lemak dari peternakan A dan B masing masing sebesar 2,8 dan 3,7\%. Kadar lemak peternakan A berdasarkan SNI 2011 masih berada dibawah kisaran normal sedangkan kadar lemak pada peternakan B sudah berada diatas kisaran normal. Susu segar dari peternakan A diperoleh dari sapi yang berada pada bulan laktasi sekitar 7 sedangkan pada peternakan B susu segar diperoleh dari sapi yang sedang pada bulan laktasi diatas 4. Faktor-faktor yang mempengaruhi kadar lemak susu sapi perah adalah jenis sapi perah, umur, masa laktasi, interval pemerahan, keadaan iklim dan ransum yang diberikan (Sumantri et al, 2005).

Kadar laktosa pada peternakan A dan B masing-masing sebesar 2,9 dan 3,0\%. Kedua peternakan ini memiliki perbedaan yang tidak terlalu berbeda. Laktosa adalah salah satu komponen susu yang akan terfermentasi oleh BAL pada proses pembuatan yoghurt (Miwada et al., 2006).

\section{Total Bakteri Asam Laktat pada Susu Bifidus}

Hasil analisis yang tercantum pada Tabel 1 menunjukkan bahwa terdapat peningkatan total BAL sebanyak 0,80 log $\mathrm{CFU} / \mathrm{ml}$ selama 6 jam inkubasi pada peternakan A. Peningkatan tersebut berawal dari total BAL susu yang sesaat telah diinokulasi (yaitu 6,93 log $\mathrm{CFU} / \mathrm{ml}$ ) yang kemudian meningkat hingga 7,73 log $\mathrm{CFU} / \mathrm{ml}$ pada jam ke-6 inkubasi. Sedangkan pada peternakan $\mathrm{B}$, terdapat peningkatan total BAL sebesar 1,08 CFU/ml (total bakteri awal inkubasi adalah 6,71 log CFU/ml dan meningkat hingga $7,79 \mathrm{CFU} / \mathrm{ml}$ pada inkubasi jam ke-6). Jumlah total bakteri di kedua peternakan berada dalam kisaran normal standar minimal bakteri asam laktat dalam yoghurt dan susu fermentasi yaitu 107 $\log$ CFU/ml (SNI, 2009). Bakteri asam laktat dapat tumbuh baik di dalam susu fermentasi tergantung pada ketersediaan nutrisi dalam media tersebut (Azizah, 2013). 
Analisis Susu Bifidus Tanpa Ekstrak Buah

Data hasil analisis susubifidustanpa penambahan ekstrak buah berdasarkan pada pertumbuhan total BAL, $\mathrm{pH}$ dan daya lekat (Adhesiveness) di peternakan A dan B disajikan pada Tabel 2.

Tabel 2. Pertumbuhan Total BAL, Penurunan Nilai $\mathrm{pH}$ dan Peningkatan Daya Lekat (Adhesiveness) Susu Bifidus Tanpa Ekstrak Buah jam ke $0-6$

\begin{tabular}{|c|c|c|}
\hline \multirow{2}{*}{ Parameter } & Peternakan A & Peternakan B \\
\hline & \multicolumn{2}{|c|}{ Rata-Rata } \\
\hline Total BAL & 0,80 & 1,08 \\
\hline Nilai pH & 0,44 & 0,50 \\
\hline Adhesiveness & 0,13 & 0,06 \\
\hline
\end{tabular}

Hasil analisis Uji-T menunjukkan bahwa rata-rata pertambahan total bateri asam laktat susu bifidus yang berbahan baku susu segar dari peternakan A dan B tidak berbeda nyata $(\mathrm{P}>0,05)$. Hal ini mengindikasikan bahwa kualitas susu bifidus dari peternakan A dan B yang tidak jauh berbeda dalam hal pertambahan total BAL. Hal ini diduga kandungan laktosa yang merupakan substrat bagi BAL dari kedua peternakan yang cenderung memiliki

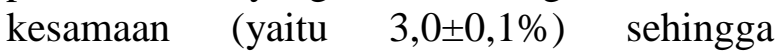
aktivitas bakteri asam laktat tumbuh secara alami sesuai dengan kurva pertumbuhan sehingga tidak menunjukkan adanya perbedaan yang nyata. Adanya stress (salah satunya adalah keterbatasan substrat yaitu laktosa), dapat berakibat pada perbedaan pola pertumbuhan BAL (Piard, 1991). Beberapa faktor yang juga dapat mempengaruhi pertumbuhan total bal antara lain kandungan komposisi kimia susu yang merupakan substrat bagi BAL, suhu fermentasi dan kultur starter. Mahdian dan Tehrani (2007), menjelaskan bahwa pertumbuhan bakteri dipengaruhi oleh beberapa faktor seperti komposisi kimia susu, jumlah inokulum, temperatur susu, waktu inkubasi, dan waktu pendinginan susu. Amin (2011) juga menjelaskan bahwa efektivitas BAL dalam menghambat bakteri pembusuk dipengaruhi oleh kepadatan BAL, strain BAL, dan komposisi media. Selain itu, produksi substansi penghambat dari BAL dipengaruhi oleh media pertumbuhan, $\mathrm{pH}$, dan suhu lingkungan.

Berdasarkan data komposisi bahan baku, peternakan $\mathrm{B}$ mempunyai kandungan lemak yang lebih tinggi daripada peternakan A. Untuk komposisi protein dan laktosa, peternakan A lebih tinggi daripada peternakan B. Dari data tersebut jelas terlihat bahwa peternakan A dan B mempunyai kandungan komposisi kimiawi yang berbeda, namun setelah proses fermentasi oleh BAL, menghasilkan pertumbuhan BAL yang tidak signifikan berbeda. Hal ini merupakan suatu informasi yang sangat bermanfaat bagi industri pembuatan susu fermentasi bahwa perbedaan kualitas bahan baku susu tidak selamanya linear dengan peningkatan BAL selama masa fermentasi.

\section{Nilai pH}

Hasil analisis nilai $\mathrm{pH}$ susu bifidus tercantum pada Tabel 2. Berdasarkan tabel tersebut, rata-rata penurunan nilai $\mathrm{pH}$ pada proses pembuatan susu bifidus selama 6 jam inkubasi adalah sebanyak 0,44 pada peternakan A. Penurunan tersebut berawal dari nilai $\mathrm{pH}$ susu segera setelah diinokulasi (yaitu 6,53) yang kemudian menurun hingga 6,09 pada jam ke-6 inkubasi (data tidak ditampilkan). Sedangkan pada peternakan B, terdapat penurunan nilai $\mathrm{pH}$ sebesar 0,50 (nilai $\mathrm{pH}$ awal inkubasi adalah 6,55 dan menurun hingga 6,05 pada inkubasi jam ke-6, data tidak ditampilkan).

Hasil analisis statistik dengan menggunakan uji-T menunjukkan bahwa penurunan nilai $\mathrm{pH}$ pada susu bifidus yang berbahan baku susu segar dari peternakan A berbeda nyata $(\mathrm{P}<0,05)$ dengan peternakan $\mathrm{B}$. Penurunan nilai $\mathrm{pH}$ pada peternakan $\mathrm{B}$ secara nyata lebih rendah dibandingkan nilai $\mathrm{pH}$ pada peternakan A. Jika dilihat dari nilai $\mathrm{pH}$ pada akhir inkubasi (yaitu jam ke-6) maka susu fermentasi dari peternakan B juga menghasilkan nilai $\mathrm{pH}$ yang lebih rendah dari peternakan A. Hal ini diduga karena komposisi kimia susu dari peternakan B mempunyai kadar laktosa yang sedikit lebih tinggi daripada susu dari peternakan A. Substrat pertumbuhan bakteri (yaitu berupa laktosa) merupakan faktor yang sangat 
berpengaruh dalam pertumbuhan BAL. Oleh karena itu penurunan $\mathrm{pH}$ yang lebih besar pada peternakan B daripada peternakan A, sangat besar kemungkinannya sebagai akibat dari tingginya kadar laktosa pada susu di peternakan B. Dijelaskan oleh Abubakar dan Syawaludin (1999) bahwa komponen yang berperan besar dalam fermentasi asam laktat adalah laktosa yang digunakan sebagai sumber energi dan sumber karbon selama fermentasi. Selain itu, adanya kadar protein yang lebih rendah pada susu dari peternakan B daripada peternakan A, juga merupakan faktor pendukung yang menyebabkan penurunan $\mathrm{pH}$ pada susu fermentasi yang dihasilkan dari peternakan B (Amy, 2014).

Berdasarkan pada Tabel 2, kisaran nilai $\mathrm{pH}$ dari kedua peternakan masih belum mencapai nilai $\mathrm{pH} 5$ dan tergolong lebih tinggi dibanding lazimnya produk susu fermentasi ( $\mathrm{pH}$ dibawah angka 5). Hal ini dapat disebabkan oleh jenis starter yang digunakan dan komposisi laktosa pada media yang digunakan. Pada penelitian ini starter yang digunakan yaitu starter tunggal Bifidobacterium longum ATCC-15750. Bakteri bifido ini tergolong bakteri heterofermentatif karena tidak menghasilkan asam laktat, tetapi juga menghasilkan asam asetat, etanol dan $\mathrm{CO}_{2}$. Jenis bakteri ini membutuhkan waktu yang lebih lama dalam memfermentasi karbohidrat dibandingkan jenis BAL yang lain seperti Streptococcus dan Lactobacillus (Hadadji, 2006).

\section{Daya Lekat (Adhesiveness)}

Adhesiveness merupakan parameter penting dalam reologi yogurt. Hasil analisis peningkatan adhesiveness pada susu bifidus tanpa penambahan buah dapat dilihat pada Tabel 2 yaitu pada peternakan A sebesar 0,13 . Peningkatan ini berawal dari sebelumnya setelah diinokulasi yaitu sebesar 0,08 menjadi 0,22. Sedangkan pada peternakan B terjadi peningkatan sebesar 0,06 yang berawal dari 0,20 menjadi 0,27. Berdasarkan hasil analisis Uji-T, adhesiveness susu bifidus yang berbahan baku susu dari peternakan A tidak berbeda secara nyata $(\mathrm{P}>0,05)$ terhadap peternakan $\mathrm{B}$. Hal ini mengindikasikan bahwa tidak terdapat perbedaan yang nyata antara adhesiveness peternakan A dan peternakan B.

Adhesiveness merupakan suatu kemampuan untuk menarik kembali permukaan pangan dengan permukaan materi yang mempunyai kontak langsung dengan pangan (Liu et al., 2008). Adhesiveness susu fermentasi mempunyai hubungan secara linear dengan kekentalan (Renata et al., 2006). Peternakan A dan Peternakan B mempunyai rataan daya rekat yang hampir sama. Hal ini diduga oleh singkatnya waktu fermentasi sehingga bakteri asam laktat belum sempurna dalam mengurai protein yang terkandung dalam susu segar dan menyebabkan daya lekat susu bifidus masih sama seperti kondisi sebelum difermentasikan.

\section{Analisis Susu Bifidus dengan Penambahan Ekstrak Buah}

Data hasil analisis susu bifidus dengan penambahan ekstrak buah dapat dilihat pada Tabel 3.

Tabel 3. Pertumbuhan Total BAL, Penurunan Nilai $\mathrm{pH}$ dan Peningkatan Daya Lekat (Adhesiveness) Susu Bifidus dengan Ekstrak Buah jam ke 0-6

\begin{tabular}{ccccccc}
\hline \hline \multirow{3}{*}{ Perlakuan } & \multicolumn{3}{c}{ Peternakan A } & \multicolumn{3}{c}{ Peternakan B } \\
\cline { 2 - 7 } & $\begin{array}{c}\text { Total BAL } \\
(\log (\mathrm{CFU} / \mathrm{ml}))\end{array}$ & $\begin{array}{c}\text { Nilai } \\
\mathrm{pH}\end{array}$ & $\begin{array}{c}\text { Daya } \\
\text { Lekat }\end{array}$ & $\begin{array}{c}\text { Total BAL } \\
(\log (\mathrm{CFU} / \mathrm{ml}))\end{array}$ & $\begin{array}{c}\text { Nilai } \\
\mathrm{pH}\end{array}$ & Daya Lekat \\
\hline $\mathrm{T}_{1}$ & 1,00 & 0,61 & 0,12 & 1,11 & 0,65 & 0,05 \\
$\mathrm{~T}_{2}$ & 1,01 & 0,54 & 0,12 & 1,07 & 0,61 & 0,08 \\
$\mathrm{~T}_{3}$ & 0,91 & 0,64 & 0,05 & 1,03 & 0,64 & 0,10 \\
Rerata & $\mathbf{0 , 9 7}$ & $\mathbf{0 , 5 9}$ & $\mathbf{0 , 0 9}$ & $\mathbf{1 , 0 7}$ & $\mathbf{0 , 6 3}$ & $\mathbf{0 , 0 7}$ \\
\hline
\end{tabular}

Keterangan: T1 adalah perlakuan ekstrak buah Alpukat, T2 adalah perlakuan buah Salak, dan T3 adalah perlakuan ekstrak buah Kelengkeng. Rerata hasil penelitian adalah dari analisis sebanyak tiga kali ulangan. 


\section{Kualitas Susu Bifidus Penambahan Ekstrak Buah}

Hasil analisis susu bifidus dengan penambahan ekstrak buah alpukat, salak, dan kelengkeng, tercantum pada Tabel 3 . Berdasarkan tabel tersebut, nampak terdapat peningkatan rata-rata total BAL sebanyak 0,97 $\log$ CFU/ml pada susu bifidus dari peternakan A dan sebanyak 1,07 log CFU/ml pada susu bifidus dari peternakan B.

Berdasarkan hasil analisis pada Tabel 3 , telah terjadi penurunan nilai $\mathrm{pH}$ sebanyak 0,59 pada peternakan A dan 0,63 pada peternakan B. Hasil analisa statistik menunjukkan bahwa pertumbuhan total bakteri asam laktat, penurunan nilai $\mathrm{pH}$ dan peningkatan adhesiveness pada susu bifidus yang berbahan baku susu dari peternakan A tidak berbeda nyata terhadap peternakan $\mathrm{B}$ $(\mathrm{P}>0,05)$.

Hasil analisis $\mathrm{pH}$, total BAL, dan adhesiveness pada susu bifidus sebelum dan ditambah ekstrak buah nampak suatu fenomena bahwa ekstrak buah, dapat berakibat pada peningkatan total BAL dan peningkatan adhesiveness serta penurunan nilai $\mathrm{pH}$ pada susu bifidus. Fenomena ini dapat disebabkan oleh penambahan oligosakarida yang terkandung di dalam ekstrak buah sehingga BAL dapat berkembang dengan cukup baik. Penambahan ekstrak buah memberikan nutrisi berlebih untuk pertumbuhan BAL. Buah mengandung gula-gula sederhana yang dapat membantu tumbuh berkembangnya Bifidobacterium longum dalam susu berupa glukosa, sukrosa dan fruktosa serta berbagai macam oligosakarida (Azizah, 2013). Penambahan buah ini akan memberi bakteri asam laktat makanan tambahan sehingga aktivitas bakteri mejadi lebih baik (Hidayat, 2012). Hal ini merupakan suatu perkembangan yang cukup baik dikarenakan dengan penambahan buah dapat meningkatkan kualitas susu fermentasi yang berasal dari susu segar yang berkualitas kurang baik. Menurut Hartati et al. (2003) yang disitasi Nurwantoro et al. (2009) menyatakan bahwa kemampuan terbesar yang dimiliki BAL dapat mendegradasi berbagai jenis gula menjadi berbagai komponen terutama asam laktat. Penambahan gula lain bermanfaat bagi mikroorganisme yang berperan dalam proses pembuatan yoghurt (Samsumaharto dan Puspawati, 2008).

\section{KESIMPULAN}

Penurunan nilai $\mathrm{pH}$ dan adhesiveness pada proses pembuatan susu bifidus tidak dipengaruhi oleh kualitas susu dari dua macam peternakan sapi perah yang digunakan dalam penelitian ini, akan tetapi macam peternakan secara signifikan menandatangani sertifikan peserta tidak pada pertumbuhan total bakteri total BAL dan daya lekat (Adhesiveness). Kualitas susu bifidus setelah penambahan ekstrak buah mengalami peningkatan dibandingkan sebelum diberi ekstrak buah. Penambahan ekstrak buah dapat meningkatkan kualitas susu serta dapat menyetarakan atau menyamakan kualitas susu bifidus yang berbahan baku susu dari peternakan yang berbeda sehingga kualiatas susu bifidus yang berbahan baku susu segar dari peternakan dengan kualitas lebih rendah menjadi dapat teratasi.

\section{DAFTAR PUSTAKA}

Abubakar dan M. Syawaludin. 1999. Perbandingan Persentase Susu Kedelai dan Susu Sapi terhadap Karakteristik Yoghurt. Seminar Nasional Peternakan dan Veteriner, Bogor.

Al-Baarri, A. N dan A. M. Legowo. 2012. Aplikasi Teknologi LactoperoxidaseSepharose-Membrane sebagai Metode Pengawetan Susu Segar yang Murah dan Aman. (Tidak dipulikasikan).

Amin dan Leksono, 2001. Efektivitas Bakteri Asam Laktat dalam Menghambat Bakteri. Airlangga. Yogyakarta.

Amy Sie Yiek Law and Min Liong Ph.D. Lactic Acid Bacteria and BifidobacteriaInhibitor Staphylococcus Epydermis. Wounds 2014:26 (5), 121-131

Azizah. N , Y. B. Pramono, dan S. B. M. Abduh. 2013. Sifat Fisik, Organoleptik, Dan Kesukaan Yogurt Drink Dengan 
Penambahan Ekstrak Buah Nangka. Jurnal Aplikasi Teknologi Pangan Vol (2) :3

Brookfield. 2014. What is Texture Analysis. Middleboro. U.S.A.

Hadadji. M and A. Bensoltane. 2006. Growth And Lactic Acid Production by Bifidobacterium Longum and Lactobacillus Acidophilus in Goat's Milk. African Journal of Biotechnology Vol. 5 (6), pp. 505-509. 2006

He Liu, Xue Ming Xu dan Shi Dong Guo. 2008. Comparison of full-fat and low-fat cheese analogues with or without pectin gel through microstructure, texture, rheology, thermal and sensory analysis. International Journal of Food Science and Technology 2008, 43, 1581-1592.

Hidayat, I. R. 2013. Total Bakteri Asam Laktat, Nilai Ph Dan Sifat Organoleptik Drink Yoghurt Dari Susu Sapi Yang Diperkaya Dengan Ekstrak Buah Mangga. Animal Agriculture Journal, Vol. 2. No. 1, 2013, p 160 - 167

Mahdian, E. and M. M. Tehrani. 2007. Evaluation the Effect of Milk Total Solids on the Relationship between Growth and Activity of Starter Cultures and Quality of ConcentratedYogurt. American-Eurasian J. Agri \& Environ Sci. 2 (5) : 587-592.

Miwada, I. N. S., S.A. Lindawati dan W. Tatang. 2006. Tingkat Efektivitas "Starter" Bakteri Asam Laktat pada Proses Fermentasi Laktosa Susu. J.Indonesia Tropic Animal Agriculture. 31 [1], 2006

Nurwantoro, Sutaryo, D. Hartanti dan H. Sukoco. 2009. Viabilitas Bifidobacterium bifidum, kadar laktosa dan rasa es krim simbiotik pada lama penyimpanan suhu beku yang berbeda. J. Indon. Trop. Anim. Agric. 34 (1): 16-21.
Permadi, S. N. 2013. Profil Protein, Sifat Fisik, Dan Total Bakteri Asam Laktat (Bal) Yogurt Drink Dengan Penambahan Ekstrak Buah Salak. Fakultas Pertanian dan Peternakan. Universitas Diponegoro. Semarang (Thesis)

Piard, J. C. and M. Desmazeavd. Inhibiting Factors Produce by Lactid Acid Bacteria. 1. Oxygen Metahabolites and Catabolism End Product. Lait (1991) 71 : 525-541

Renata B. Magenis, Elane S. Prude^ncio, Renata D. M. C. Amboni, Noel G. Cerqueira Ju'nior,1 Ricardo V. B. Oliveira,2 Valdir Soldi2 \& Hono' rio D. Benedet.2006. Compositional and Physical Properties of Yogurts Manufactured from Milk and Whey Cheese Concentrated by Ultrafiltration. International Journal of Food Science and Technology 2006, 41, 560-568.

Samsumaharto, R. A dan N. Puspawati. 2008. Perbandingan fermentasi yoghurt susu biji asam (Tamarindus indica, L.) dengan yoghurt susu murni. Jurnal Kimia dan Teknologi. 1: 263-274.

Standarisasi Nasional Indonesia (SNI). 2009. SNI 2981:2009. Yoghurt. Badan Standardisasi Nasional (BSN), Jakarta.

Standarisasi Nasional Indonesia (SNI). 2011. SNI 3141.1:2011. Susu Segar-Bagian 1 : Sapi. Badan Standardisasi Nasional (BSN), Jakarta.

Sumantri. S, R.R.A. Maheswari, A Anggraeni, K. Diwyanto dan A. Farajallah. 2005. Pengaruh Genotipe Kappa Kasein (K-Kasein) terhadap Kualitas Susu pada Sapi Perah FH Di BPTU Baturraden. Seminar Nasional Teknologi Peternakan dan Veteriner. Fakultas Peternakan Intitut Pertanian Bogor.Bogor 